\title{
Aviation Employment in the US: A Review of Data Sources
}

\author{
David A. NewMyer, Ph.D. and Russell T. C. Owen \\ Southern Illinois University
}

\begin{abstract}
The aviation industry - particularly the airline and aviation/aerospace manufacturing segmentshas received significant negative attention due to financial and employment losses that it has suffered since the terrorist attacks of September 11, 2001. For example, nearly 150,000 jobs have been reported cut at the airlines and aviation/aerospace manufacturers combined. However, there is little said about the overall aviation industry backdrop for these cuts: How large is US aviation industry employment after these publicly announced cuts? The problem addressed by this research was one of finding sources to determine the overall size and scope of aviation industry employment in the US. A literature review was used that examined government documents, scholarly journals, aviation industry journals and information provided by aviation industry associations. In addition, the results of a telephone survey of the top 100 airline-served airports in the US were utilized. The literature review found that US aviation industry employment as of 2002 ranged from 1,870,400 to 2,169,845 depending on the data sources used to arrive at the total. It was also concluded that there are data details not available from the US Department of Labor employment statistics on the aviation industry that are important to determining a conclusive aviation industry employment estimate.
\end{abstract}

\section{INTRODUCTION}

Considering the negative economic and employment impacts of the post-9/11 era, the Iraq War and Severe Acute Respiratory Syndrome (SARS), the US aviation industry has been reeling. There were reports not long after the 9/11 attacks that US domestic airlines had furloughed or terminated over 150,000 employees and companies already in economic distress were failing, or filing for protection under Chapter 11 of the US Bankruptcy Code (Moylan, 2002). Since the Iraq War started, even more layoffs have been reported (Air Transportation Association of America, 2003b). The problem that arises when these reports appear is that it is difficult to put them into in aviation industry-wide context. That is, when a layoff of 150,000 people happens, yes, it is an important impact. However, how important, or, how large is it considering the entire industry, or just considering the airline segment of the aviation industry? This leads to the question: Where does one obtain aviation industry employment data? What sources are there for the industry as a whole, and by key industry segment, and how do they compare to one another?
The purposes of this paper will be to: (1) provide an assessment of the various aviation industry employment sources, (2) present employment information for the key aviation industry segments: Aviation/Aerospace, Airlines, General Aviation, Government and "other" and (3) present a literature review of aviation industry employment sources, with a goal to find the total aviation industry employment number for calendar year 2002.

\section{Definitions}

For the purposes of this paper, the following definitions were used:

1. Aviation/Aerospace Manufacturing included the subcategories of Military/Defense (aircraft, missiles, electronics), Civil (airline and general aviation; fixed wing and rotorcraft), and Space. These categories are all included in various definitions of the aviation/aerospace manufacturing segment provided by the Aerospace Industries Association of America or AIAA (Napier, 2002).

2. Airlines will include majors, nationals, large regionals and medium regionals, as defined 
by the US Department of Transportation (Wells, 1999).

3. General Aviation will include companies and entities involved in "... all flying except that conducted by the military or the airlines" (General Aviation Manufacturers Association, 2003). Examples include general aviation fixed based operators, fueling companies, charter companies, corporate flight departments, fractional ownership companies, pipeline inspection companies using aircraft, flight training companies (and individuals who provide flight instruction), flying clubs, privately owned airports, agricultural operators and the like. General aviation manufacturing will be included under aviation/aerospace manufacturing.

4. Government will include non-military federal, state and local government entities that are involved in aviation. This category would include airports owned and operated at any level of government, state aviation agencies, and also would include the Federal Aviation Administration, the Transportation Security Administration of USDOT, and aviation components of agencies like the Immigration and Naturalization Service, Customs, Forestry, etc.

5. Other would include those entities not covered in prior categories such as the aviation aspects of travel agencies, university and college aviation programs, and other special entities.

\section{METHODOLOGY}

This study is, in part, a replication of an earlier study done by NewMyer, Kaps and Sharp that reported on 1995 aviation industry employment levels. This study was published in the Journal of Aviation/Aerospace Education and Research in Spring 1997 and reported an overall US aviation industry employment of $2,185,644$. World events affecting the aviation industry, the availability of new aviation employment data sources, and the advent of increased access to employment data from online sources prompted the current study. A literature review was employed in this study, with one exception. The one exception is that an unpublished survey of employment at the top 100 airline-served airports in the US (conducted by the authors of this article) was utilized. While the details of this survey will be the subject of another future publication, the results were used in this article to help establish an employment number for local government owned airports. Included in the review of literature were articles published in such scholarly journals as Journal of Aviation/Aerospace Education and Research as well as information obtained from aviation industry publications such as Aviation Week and Space Technology. Information was also obtained from various government agencies related to aviation such as the Federal Aviation Administration, the Bureau of Transportation Statistics of the US Department of Transportation, Customs and the Transportation Security Administration. In addition, information about aviation employment was obtained from aviation industry associations such as the Aerospace Industries Association of America, Airport Council InternationalNorth America, Air Transport Association of America, National Air Transportation Association and National Association of State Aviation Officials. Finally, aviation employment information was utilized from the United States Department of Labor.

\section{OVERALL AVIATION INDUSTRY DATA SOURCES}

The NewMyer, Kaps and Sharp Study (1997)

This study reported the following US civilian aviation employment data for the year 1995:

$\begin{array}{lr}\text { Aviation/Aerospace Manufacturing } & 778,000 \\ \text { Airlines } & 640,453 \\ \text { General Aviation } & 339,891 \\ \text { Government } & 85,389 \\ \text { Miscellaneous (other) } & 341,911 \\ \text { TOTAL } & \mathbf{2 , 1 8 5 , 6 4 4}\end{array}$

Source: NewMyer, D. A., Kaps, R. W., and Sharp, S. E., Aviation Industry Employment Data Estimates Revisited, JAAER, Spring 1997, pp 7-18. 
This study used US Department of Labor, Bureau of Labor Statistics data sparingly, and did not use airline employment data from the Bureau of Transportation Statistics, US Department of Transportation at all. It also used a study from 1979 as a key basis for the estimate of general aviation employment. With that study 24 years old at the time of the present study, it had to be totally replaced with another, more recent source. Finally, government employment figures were based on a combination of surveys (one of employment at the top 50 airports), government data and estimates. A much tighter, more focused estimate of US aviation employment is now possible.

\section{US DEPARTMENT OF LABOR DATA}

One of the most authoritative sources of information on employment in the US is the United States Department of Labor (USDOL). The USDOL classifies industries using the Standard Industrial Classification (SIC). SIC Group 45 is "Transportation by Air." This group includes "establishments engaged in furnishing domestic and foreign transportation by air and also those operating airports and flying fields and furnishing terminal services" (Office of Management and Budget, 1987). The Department of Labor states that there are $1,251,430$ people employed in the Transportation by Air group, or SIC code 45, as of March 1, 2003 (US Department of Labor (2003). When collecting the data from the Department of Labor, there are two numbers: seasonally adjusted and non-seasonally adjusted. The difference between these two statistics is that seasonal adjustment uses a technique to account for holidays, weather, economic factors and other influences on the work force. The seasonal adjustment numbers are reported here.

The SIC then narrows the "transportation by air" group down further into sub-groups, for example, Major group 45 (Transportation by Air), Industry group Number 1 , Industry number 2 . This combines to 4512, which is "Air Transportation, Scheduled" (Table 1), a sub-group of SIC Group 45. The 4512 Industry group includes all companies that furnish air transportation over regular routes and on regular schedules. This industry classification includes scheduled air cargo carriers and scheduled air passenger carriers. A total of 508,700 are employed in this group as of April 4, 2003 (USDOL).

Industry classification 4513 is "Air courier services." The definition that the SIC of an air courier is "...anyone who furnishes air delivery of letters, parcels and packages generally under 100 pounds" (OMB). Other couriers that engage in providing pick-up and delivery, "drop-off points", or distribution centers are all classified under this industry code. Companies that fit into this code include: air courier services, private letter, package and parcel delivery through the air. The United States Postal Service is located under Industry 4311, while other delivery services are classified in Industry 4215 , and yet other delivery services are classified in Industry 4731 (OMB). The data can be included in many of the classifications. Therefore, aviation industry employment data can be accounted for in many industrial classifications, which does not always give the researcher a clear picture of exact employment totals in the aviation industry within the USDOL data.

Industry classification 4522 (see Table 1) is reserved for "Air transportation, nonscheduled." This group consists primarily of airplane sightseeing services, air taxi services and helicopter passenger services to and from local airports, air cargo carriers, air taxi services, air ambulance services, flying charter services, helicopter services and others (OMB, 1987).

The airports, flying fields and airport terminal services fall under SIC 4581 (see Table 1). These are defined as "primarily engaged in operating and maintaining airports and flying fields" (OMB, 1987). This industry also includes air traffic control operations except government air traffic control (ATC) employees. Total employment for the 4581 group is 141,800 as of April 4, 2003 (USDOL, 2003). Federal Aviation Administration Air Traffic Control (ATC) employees are located in classification 9621 (Public Administration) and the data cannot be retrieved due to the fact that this grouping includes far more than just air traffic controllers. Aviation clubs are located in group 7997, which employs 341,000 people overall. However, 
again, there is no detail for the reader to discover what the aviation-related component of this group would be. (USDOL, 2003).

Aviation/aerospace manufacturing data can be found in SIC Goup 37 (see Table 2). This group is referred to the transportation equipment group. Some of the important aviation-related manufacturers found in this group produce aircraft (military and civil), rotorcraft, space vehicles, and missiles. Also, 3721 is the SIC code for aircraft and its parts. This group includes all establishments that manufacture or assemble complete aircraft. Moreover, this group also includes any organization that owns their own aircraft while conducting research and development. Some examples of items classified in 3721 are: aircraft, blimps, gliders, helicopters, airships and various other "aircraft". Repairing and rebuilding aircraft on a factory basis are also included in the definition of 3721 . The total employment for this group is 491,900 as of April 4, 2003 (USDOL).

Table 1

US Department of Labor Employment Data for Industry Group 45: "Transportation by Air"

(All Employees, Thousands)

$\begin{array}{ccccc}\text { Year } & \begin{array}{c}\text { Total } \\ (45)\end{array} & \begin{array}{c}\text { Air Transportation } \\ (451)\end{array} & \begin{array}{c}\text { Air Transportation } \\ \text { Scheduled } \\ (452)\end{array} & \begin{array}{c}\text { Airports, } \\ \text { Flying Fields }\end{array} \\ 2000 & 1,279.9 & 1,085.2 & 582.5 & 146.5 \\ 2001 & 1,266.0 & 1,070.3 & 581.2 & 145.4 \\ 2002 & 1,161.4 & 970.9 & 508.7 & 141.8\end{array}$

SOURCE: US Department of Labor, Bureau of Labor Statistics, 2003

Table 2

US Department of Labor Data for Industry Group 37: Aviation/Aerospace Manufacturing

(All Employees, Thousands)

\begin{tabular}{|c|c|c|c|c|c|c|}
\hline Year & $\begin{array}{l}\text { Total } \\
(372)\end{array}$ & $\begin{array}{c}\text { Aircraft } \\
\text { (3721) }\end{array}$ & $\begin{array}{l}\text { Aircraft } \\
\text { Engines \& } \\
\text { Engine Parts } \\
\quad(3724)\end{array}$ & $\begin{array}{l}\text { Aircraft Parts } \\
\& \text { Equipment } \\
\text { nec. }{ }^{*} \\
\text { (3728) }\end{array}$ & $\begin{array}{l}\text { Total } \\
(376)\end{array}$ & $\begin{array}{l}\text { Guided } \\
\text { Missiles } \\
\text { \& Space } \\
\text { Vehicles } \\
(3761)\end{array}$ \\
\hline 2000 & 464.1 & 233.9 & 100.6 & 129.6 & 86.3 & 59.2 \\
\hline 2001 & 460.6 & 232.6 & 98.9 & 129.1 & 83.7 & 57.6 \\
\hline 2002 & 410.2 & 205.5 & 92.4 & 112.3 & 81.7 & 56.0 \\
\hline
\end{tabular}

SOURCE: US Department of Labor, Bureau of labor Statistics, 2003

* Not elsewhere classified 
Group 3724 (see Table 2) classification includes aircraft engines and parts. Aircraft parts and auxiliary equipment not elsewhere classified is in Group 3728. This group employs 92,400 as of February 12, 2003. Space vehicles are classified as 3761, and employ 56,000 as of February 12, 2003. Finally, research and development on aircraft not owned by the manufacturer is classified in the Services industry 8731 which shows an employment level of 263,400. Again, the aviation detail is lost in the total and can not be retrieved.

The Aviation/Aerospace Manufacturing industry as reported in USDOL statistics, spreads the data across many groups and subgroups and totals. Overall, the USDOL aviation/aerospace employment total is 689,000 (USDOL, February 12, 2003).

The major group 96 is where one can find the administration of economic programs. Specifically, 9621 includes the regulation and administration of transportation programs. Moreover, this section includes government air traffic control operations as well as government aircraft inspections. However, 4581 is the code that is used to classify private air traffic control operations. Therefore, given the information previously provided about government ATC employees being contained in Group 9621, two completely different classification groups count the same job, just in different sectors (public and private) (OMB, 1987).

\section{Airport Council International - North America Study}

Airports Council International -North America (ACI-NA) reported in a study of the economic impact of US airports that U.S. scheduled passenger enplanements were estimated to be 683 million for 2001 and expect to be over a billion by 2013 (ACI-NA, 2002, p.1). The employment growth rate during that time is expected to be nearly $33 \%$ in ten years. (ACI-NA, 2002, p.1). That is an average annual growth rate of $4 \%$. ACI-NA also states that there are, "1.9 million jobs on airports in the U.S., and 4.8 million are created in local communities, for a total of 6.7 million airport related jobs" (ACINA, 2002, p.1).

\section{AVIATION INDUSTRY DATA SOURCES BY INDUSTRY SEGMENT}

\section{Aviation Industry Association Employment Data by Industry Segment}

Aerospace Industries Association of America (AIA), which represents the nation's aerospace manufacturers, published a "white paper" on January 23, 2003 that stated, "Since September 11, 2001, aerospace employment has fallen approximately 93,000 - to the lowest level since before 1953" (AIA). On March 4, 2003, AIA issued a press release entitled "Aerospace Employment Hits 50-Year Low" in which it stated, "U. S. aerospace employment has reached its lowest level since 1953-dropping to 689,000 at the end of 2002."

Air Transport Association of America, the association that represents larger airlines operating in North America, made this statement in their 2002 Annual Report: "One of the unfortunate outcomes of the terrorist attacks is that most airlines had to reduce their workforces. Airlines initially announced layoffs and furloughs of roughly 100,000 employees" (ATA). The report noted that the total drop in employment from year-end 2000 to 2001 employees in full time equivalent numbers was only from 679,967 to 670,730 . However, these numbers included employment for associate members of ATA from other nations. The 2001 ATA employment figure for US airlines who were members of ATA was reported as 624,197 (ATA).

The National Air Transportation Association (NATA) is a Washington, D. C.based aviation association that represents the aviation services segment of aviation. Aviation services employment is a key part of general aviation. Nearly 2,000 businesses owning, operating and servicing aircraft are a part of NATA. The members of this organization represent a key component that links the industry, airlines, general aviation and the military. "There are approximately 5,000 aviation service business locations nationwide" (NATA, p.1).

Aviation businesses are the foundation that supports the air transportation industry. Most of these businesses are fixed-base 
operators (FBO's), who provide ground services to the aircraft owners and operators. There can be many services provided by the FBO, much of which is determined by location, competition, experience and airport requirements. According to the NATA, the general aviation industry employs approximately 638,000 . In addition, the general aviation industry's economic activity is $\$ 64.5$ billion (NATA, p.13). NATA does not give any indication of how they arrived at this figure nor do they indicate its composition (manufacturing, FBO's, corporate flight departments, flight training companies, and other such categories are not included).

The National Association of State Aviation Officials (NASAO) conducted an extensive study in October 2001 to collect the employment figures for state aviation commissions and departments that administer and oversee aviation activities in the 50 states.

The total number of employees reported by NASAO at such state agencies, as of 2001 was 7,792 state employees for the 50 states excluding Puerto Rico and Guam (NASAO, 2001, p.i). When re-examining the numbers it was revealed that states such as Hawaii and Maryland had higher employment numbers in proportion to most other states, and in disproportion to their relative size and share of US aviation activity. Further examination of the NASAO data showed that certain states counted employees at state-operated airports and employees flying state-operated aircraft, and sometimes (but not always) included those employment figures as a separate number. By verifying these airport and aircraft-related employment figures, and then adding them to the total where needed, the total statewide employment figures reached a new total of 9,993 (Figure 1). This reflects an addition of 2,201 additional employees added to the total aviation employment at state aviation agencies, due to adding additional operational employees (NASAO, 2001).

\section{Airline Employment Information from the Bureau of Transportation Statistics}

The Bureau of Transportation Statistics (BTS) of the US Department of Transportation collects employment statistics for certificated air carriers on an annual basis. Their year-end 2002 report of the major (i.e., $\$ 1.0$ billion or more in gross annual revenues) airlines shows a total of 489,662 full time employees, 96,228 part time employees and a total of 585,890 employees. In addition, BTS reported that there were 54,470 full and part time employees at national airlines (i.e., those with $\$ 100$ million to $\$ 1.0$ billion in gross annual revenues). Also, large regional airlines (i.e., $\$ 10$ million to $\$ 100$ million in gross annual revenues) were reported to have 3,285 full and part time employees while medium regionals (i.e., below $\$ 10$ million in gross annual revenues) had 1,152 total full and part time employees. The airline industry-wide total employment level at the end of 2002 was report to be 642,797 .

\section{Agency-reported Aviation Employment at the Federal Level}

Many agencies in the Federal Government are active in the aviation industry. First and foremost is the Department of Transportation. This Department includes the Federal Aviation Administration (FAA). The current count of FAA employees is 50,157 as of February 2003 (E. Nelson, personal communication, February 21, 2003). The US Department of Transportation's total number of employees is 68,290 (US Department of Transportation, 2003). Included in this number are 36,580 Coast Guard personnel who perform what are essentially military duties. Without the Coast Guard figures, the total employment at USDOT is 31,710 (USDOT). Of this number, it is estimated that an additional 1,000 employees are in the aviation field. This is due to the fact that USDOT still regulates the economics of air transport. The actual number was not found. Yet another reason to have standard, detailed, modalreporting procedures for Federal Agencies is so the data can be retrieved. The largest number of employees related to the aviation industry employed by the Federal government is within the Transportation Security Administration (TSA). The TSA employs around 58,000, including administration as well as baggage screening and checking (Transportation Security 
Administration, n.d). Therefore, these three federal agencies alone employ approximately $109,157$.

In addition to the data reported for the three federal agencies so far, there are several other federal agencies with a role in aviation. For example, the State Department has an Office of Aviation Negotiations that employs twenty people (J. Byerly, personal communication, March 25, 2003). This office works hand in hand with the Department of Transportation and FAA in negotiating treaties and other international agreements. The Department of Agriculture has 159 aerial firefighters (G. Wilson, personal communication, March 25, 2003). These firefighters are actually placed in the Fire and Aviation Management division within the USDA. The Department of Interior houses the Bureau of Indian Affairs, which employs eleven aviation workers (J. Stires, personal communication, March 26, 2003). The INS Border Patrol has no data that can be retrieved. The Office of Air and Marine Interdiction currently has over 400 pilots in the program (L. Sabawa, personal communication, March 25, 2003). This office is under the Customs and Department of Justice. Finally, there is NASA that houses the Division of Aeronautics. NASA employs 18,190. Overall, there are 127,967 employees in the federal government that are directly involved in the aviation/aerospace industry (see table 3 )

\section{AIRPORT SURVEY DATA}

A survey conducted by researchers at Southern Illinois University Carbondale extracted the direct and indirect employment of the nation's top 100 busiest commercial (airline served) airports in the US. This survey was conducted during the period of January through March 2003. This telephonic survey resulted in a $100 \%$ response rate. A total of 37,088 employees were found by the survey to be directly employed with the airport operators of these top 100 airports. The study also showed that there are 689,316 employees that are indirectly employed at the airports surveyed. This figure reflects employees at airlines, terminal concessionaires, automobile parking companies, rental car companies, etc. This second figure shows the economic impact of what an airport can bring to a city. However, the first figure is important since airport-specific employment data are hard to acquire and are essentially unavailable in the literature. Therefore, note that there are no other airportspecific data sources to use to report airport agency employment, other than those already reported via this survey and via the NASAO data.

Table 3

Agency-Reported Employment at the Federal Level

Agency

Transportation Security Administration

Employment Number

Federal Aviation Administration, Dept.

58,000

50,187

$\begin{array}{lr}\text { of Transportation (est. for aviation economicRegulation) } & 1,000\end{array}$

USDA (Aerial Firefighters)

159

Bureau of Indian Affiars

State Department (Office of Aviation Negotiations)

Customs (Pilots)

400

NASA

18,190

Total

127,967

SOURCE: Government Websites, Telephone Interview, and E-mails. 


\section{The "Other" Category of Aviation Employment}

In the NewMyer, Kaps and Sharp study (1997), this category was counted as having the following employees:

Travel Agencies

300,000

Consultants (including construction) $\quad 10,000$

Industry Associations

500

Aviation Educators

Related Industries

2,500

Air Cargo/Air Freight Forwarders

TOTAL

Current travel agency employment figures are available from USDOL, and they indicate the following:

Table 4

US Department of Labor Data for Industry Group 4724, Travel Agencies

(All Employees, Thousands)

$\begin{array}{ccc}\text { Year } & \text { Total } & \text { Travel Agencies } \\ & (472) & (4724) \\ 2000 & 219.5 & 170.3 \\ 2001 & 208.5 & 160.5 \\ 2002 & 183.3 & 138.5\end{array}$

SOURCE: US Department of Labor, Bureau of Labor Statistics 2003

It is clear that travel agency employment has dropped significantly since the highs reached in the mid-1990's. With the impact of Internet sales of airline tickets, and the reduction of commissions paid to travel agencies by airlines, the role of travel agencies in booking airline travel has dropped significantly in the last eight years. On top of that, the estimate of aviation industry-related impact within the 1995 data was likely overstated. Therefore, the estimate of aviation industry employment impact from travel agencies today is estimated at 20,000 employees. In addition, 5,000 more employees should be added to this category to account for any other categories of aviation employment that were not accounted for elsewhere.

\section{ANALYSIS OF DATA SOURCES}

There are several problems with the current classification of aviation industry data as provided by the USDOL. First, aviation employment data are scattered over different industry groups of statistics. For example, aviation employment data can be found in the following SIC groups: 372, 376, 45, (including 4581, etc) 7977, 8731 (see Table 5), 9621 and other classifications. A second problem is that data detail is not always available. For example, group 7977 is where you would find employment for flying clubs and flying fields maintained by aviation clubs. Unfortunately, there is not a detailed breakdown within this group so the detailed data is not available by mode. Therefore the actual employment data that is reported to the public by the DOL for the aviation industry is sometimes incomplete. Third is the question of where the "general aviation" segment of the US Civil Aviation system falls within the USDOL classification system. The answer seems to be that it falls into many of the groupings previously mentioned, but with not enough detail in the reports to determine if a particular aspect of general aviation is included or not. Examples would be flight departments maintained by non-aviation companies and businesses. Another would be off-airport flight simulation companies. Another is aviation parts supply companies. Another is employment for the 50 state departments or commissions devoted to aviation. There are aviation industry-based employment statistics for some of these categories but it is difficult to verify such data within the USDOL data. So, in reality no one knows the employment data of the general aviation industry segment using USDOL data, due to the fact that general aviation is not used as a USDOL grouping or category, or subcategory, when collecting USDOL employment data. In addition, there are fractional ownership companies such as Netjets (Executive Jet Aviation). This company already owns and operates over 500 aircraft and employs over 1,800 pilots (John Lieber, Personal Communication, April 26, 2003). The fractional ownership concept is very new and, as with other categories of general aviation, it is not clear where these data are located within the 
USDOL groups. Another similar category of general aviation is the category of corporate flight departments. This category of aviation has been a key alternative mode of air transportation during the post-9/11 era. As corporate employees find it more difficult to take airline trips, they have turned to corporate aviation. Again, it is not clear where this category of aviation employment falls within USDOL data. Finally, government-related aviation employment is not accessible in the USDOL data. It generally appears that these data are buried in the 'public administration' grouping of data. Also, it is not totally clear what the sub-grouping 'Airports and Flying Fields' includes.....is this an attempt to include 'general aviation' or is it a category strictly allocated to airport-related employees (managers, operations personnel, grounds maintenance, terminal maintenance, etc). The SIC classification is not clear on this point.

Another issue was identified when examining employment at state aviation organizations as collected by NASAO. At first, it was not clear that the total number of employees could realistically be determined for each state. And, in some cases, it looked like some states have overstated employee counts. For example, Maryland has 474 state aviation employees. However, separately, they also reported that 471 employees were assigned to operate either aircraft or airports. Using this knowledge you can see that there are only 3 full time state aviation agency employees who run the agency itself while the rest operate airports

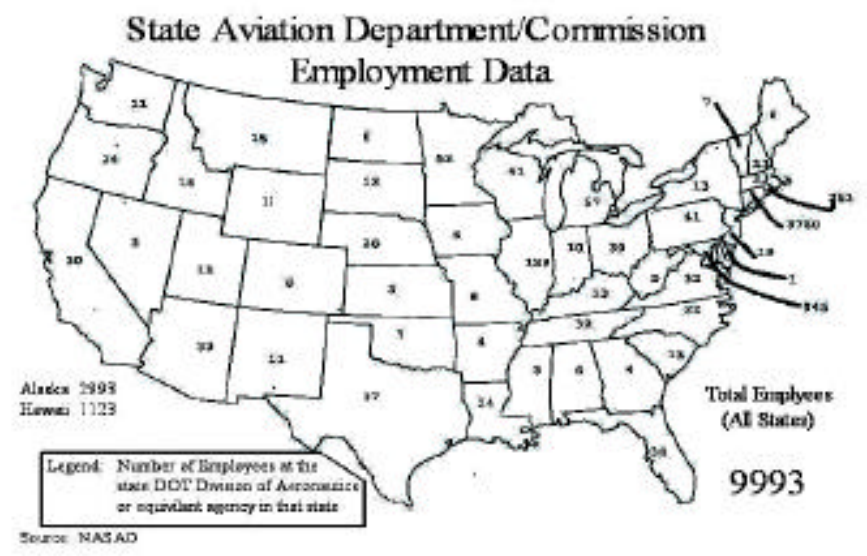

Figure 1 throughout the state. Some states did not have numbers that were quite this extreme. For example, Idaho owns four aircraft while one is leased, but they have two employees assigned to operate these aircraft (NASAO).

Determining the correct number of employees even by the state aviation agency can get confusing. For example, Hawaii and Maryland alone have a discrepancy of over 1,500 employees combined, depending on how the reader and state interpret and report the data, respectively. This is why there needs to be a uniform way of reporting such data, so the government and the aviation industry can get a clear account of how many employees are in the aviation industry as a whole.

\section{CONCLUSIONS}

The purpose of this paper was to: (1) provide an assessment of the various aviation industry employment sources, (2) present employment information for the key aviation industry segments: Aviation/Aerospace, Airlines, General Aviation, Government and "other" and (3) present a literature review of aviation industry employment sources, with a goal to find the total aviation industry employment number for calendar year 2002 . The following conclusions were reached regarding each item above.

\section{An assessment of various aviation employment sources.}

As already noted, there are two 'soft' employment figures listed in the previous pages, one for general aviation and one for the "other" category. However, it is interesting that the BTS airline number plus the NATA number adds up to $1,280,797$, which is only 119,397 off of the USDOL number $(1,161,400)$ for 'Transportation by Air'. This difference can be accounted for by the fact that the USDOL number is more recent (2003) than either the BTS or NATA numbers which are from 2002 and 2000, respectively. In fact, if one used the 2000 USDOL number for 'Transportation by Air' the numbers are very close: 1,279,900 for USDOL and 1,280,797 for the BTS/NATA combination, or only 897 employees apart. 
The advantage of using the federal, state and local government numbers in the 'combination' estimate is that these numbers are from verified sources and, in both the federal and local cases, are understated. In addition, there is no duplication or overlap among these independent sources of data. In the case of the federal numbers, there were some federal agencies for whom an employment number was not available. With regard to local government employees in aviation, the only 'hard' numbers are for the top 100 busiest airline-served airports. Since there are 19,306 landing facilities in the US, of which 5,315 are public use, and since there are another 535 certificated airports (in addition to the 100 surveyed) in the US (certificated to receive passenger airline service with aircraft over 30 passengers) (Federal Aviation Administration, 2002), it is clear that there are likely many more employees employed by local governments at airports. Therefore, it appears that some parts of this second US aviation employment number might be under-estimated.

Overall, the various sources discovered in this literature review provide a range of US aviation industry employment of between $1,870,400$ and $2,169,845$. The average of these two numbers is $2,020,123$ employees. Note that the highest number of employees found in this current study is close to the number reported by NewMyer, Kaps and Sharp in 1997, which was 2,185,644. The current number has been reached with somewhat higher levels of confidence, with the exceptions noted. Also, the number of employees counted as 'miscellaneous' in the 1997 study was quite high $(341,911)$ compared to the number used in the current study $(25,000)$.

\section{Aviation Industry Employment by Segment and Total Aviation Employment Number for 2002.}

Arriving at a total US aviation industry employment number for the year 2002, using the information presented in this paper, will require one of two things:

1. The exclusive use of US Department of Labor data, or,
2. The use of some combination of numbers from the US Department of Labor and other sources.

First, using only USDOL data, there are two key industry numbers to report and they are for 'Transportation by Air' and for 'Aviation/Aerospace Manufacturing.' The latest numbers available in those two categories total to the following aviation industry employment number:

Transportation by Air

Aviation/Aerospace Manufacturing $\quad 689,000$

Total

$\mathbf{1 , 8 7 0 , 4 0 0}$

If a combination of data sources is used to arrive at a total aviation industry employment number, this is the number that is reached:

Aviation/Aerospace Manufacturing $\quad 689,000$ (USDOL)

Airlines (BTS Figures)

642,797

General Aviation (NATA)

638,000

Federal Government (Contacts) $\quad 127,967$

State Government (NASAO) $\quad 9,993$

Local Government (Survey) 37,088

Other (Estimated From Travel Agencies

Agencies, College Aviation Programs $\quad 25,000$

Total US Aviation Employment $\quad \mathbf{2 , 1 6 9 , 8 4 5}$

While it is clear that any of the newlyestimated numbers are likely still a bit high and do not reflect the latest downside impacts of SARS and the Iraq war, it is also clear that there are on the order of 2.0 million people employed directly in some facet of the US aviation industry. This important number must be kept in mind as we as a nation consider any number of policy decisions that might positively or negatively affect the aviation industry. The aviation industry, considered as a whole, is a significant US employer, is a key net exporter of manufactured goods, transports millions of people annually, and provides access to over 19,000 airport locations nationally. And, when the US economy starts to rebound, the US aviation industry will help lead the way back to prosperity with excellent employees providing excellent products to the world. 


\section{Reference List}

Aerospace Industries Association (2003, March 4), Aerospace employment hits 50-year low. Retrieved April 30, 2003 from http://www.aia-aerospace.org/

Aerospace Industries Association (2003, January 23), Develop a national plan for revitalization of the aerospace workforce. Retrieved April 30, 2003 from http://www.aia-aerospace.org/

Airports Council International - North America (2002), The economic impact of U.S. airports 2002. Retrieved January 22, 2003, from http://www.aci-na.org.

Air Transport Association of America, Inc. (2003a, March) Airlines in crisis: The perfect economic storm. Washington, D. C., Air Transport Association

Air Transport Association of America, Inc (2003b) Airlines Seeing War Impacts. Retrieved on April 22, 2003 from http://www.airlines.org/

Air Transport Association of America, Inc. (2002), 2002 Annual report. Washington, D. C.: Air Transport Association

Bureau of Transportation Statistics, US Department of Transportation (2003) National Transportation Statistics 2002, Table 1-3: Number of U.S. Airports. Retrieved April 30, 2003 from http://www.bts.gov/

Bureau of Transportation Statistics, US Department of Transportation (2001) Number of employeesCertificated carriers 2001. Retrieved February 5, 2003 from http://www.bts.gov/oai/employees/2001emp.html

Federal Aviation Administration (2002, August 28) FAA Report to Congress - National Plan of Integrated Airport Systems (2001-2005). Retrieved June 3, 2003 from http://www1,faa,giv.arp/planning/npias 2001/npias01.htm

General Aviation Manufacturers Association (2003) What is GA?. Retrieved April 30, 2003 from http://www.gama.aero/aboutGAMA/whatisGA.php

Jackman, F. (Ed.). (2002, Spring/Summer). World aviation directory. Miami: McGraw Hill

Morrell, P. S. and Alamdari, F. (2002, January) The impact of 11 September on the aviation industry: Traffic, capacity, employment and restructuring. Geneva: International Labour Office

Moylan, M. J. (2002, October 19) "Bill helps laid-off airline workers," in Pioneer Press, Retrieved December 10, 2002 from http://www.twincitie s.com/

Napier, David (2001) Aerospace industries association of America year - end review and forecast. Retrieved November 16, 2002, from http://www.aia-aerospace.org/.

National Aeronautics and Space Admin istration. (2003) NASA workforce. Retrieved March 25, 2003, from http://nasapeople.nasa.gov/workforce/default.htm.

National Air Transport Association. (2000). Aviation businesses and the services they provide. Alexandria, VA. 
National Association of State Aviation Officials. (2001). State Aviation Funding and Organizational Data. Annual report fiscal years 2000 and 2001. Washington, D. C., National Association of State Aviation Officials.

NewMyer, D. A., Kaps, R. W., and Sharp, S. E. (1997, Spring) “Aviation Industry Employment Data Estimates Revisited" in the Journal of Aviation/Aerospace Education and Research (7) (3), Daytona Beach: Embry Riddle Aeronautical University

Office of Management and Budget. (1987). Standard industrial classification manual. Office of Management and Budget. (NTIS No. PB 87-100012).

Transportation Security Administration. (n.d). TSA facts. Retrieved April 1, 2003, from http://129.33.119.130/public/display?theme=39\&content=510.

United States Department of Labor. (2003). 2003 Bureau of Labor Statistics for Industry Retrieved April 4, 2003, from http://www.bls.gov/.

United States Department of Labor. (2003). 2003 Bureau of Labor Statistics for Industry. Retrieved February 12, 2003, from http://www.bls.gov/.

United States Department of Transportation (2003) Budget in Brief. Retrieved April 23, 2003 from http://www.dot.gov/bib/fte.html

Wells, A. T. (1999). Air transportation: A management perspective ( $4^{\text {th }}$ ed.). Belmont, CA: Wadsworth Publishing Company. 


\section{APPENDIX A}

State Aviation Agency Employment

State by State Employment according to NASAO 2001

\begin{tabular}{|c|c|c|c|}
\hline State & $\begin{array}{l}\text { Number of } \\
\text { Employees }\end{array}$ & $\begin{array}{c}\text { Agency } \\
\text { Organization }\end{array}$ & Operational Employees \\
\hline $\mathrm{AL}$ & 6 & Other & \\
\hline $\mathrm{AK}$ & 2,500 & Mode & 493 \\
\hline$A Z$ & 18 & Other & 15 \\
\hline AR & 4 & Mode & \\
\hline $\mathrm{CA}$ & 30 & Mode & \\
\hline $\mathrm{CO}$ & 8 & Mode & \\
\hline $\mathrm{CN}$ & 3,780 & Mode & \\
\hline $\mathrm{DE}$ & 1 & Function & \\
\hline $\mathrm{FL}$ & 30 & Mode & \\
\hline $\mathrm{GA}$ & 4 & Mode & \\
\hline $\mathrm{HI}$ & 105 & Mode & 1018 \\
\hline ID & 13 & Mode & $5^{*}$ \\
\hline IL & 100 & Mode & $29^{*}$ \\
\hline IN & 9 & Mode & $1^{*}$ \\
\hline $\mathrm{IA}$ & 6 & Mode & \\
\hline $\mathrm{KS}$ & 3 & Mode & \\
\hline $\mathrm{KY}$ & 13 & Mode & \\
\hline LA & 14 & Function & \\
\hline $\mathrm{ME}$ & 6 & Function & \\
\hline$M D$ & 474 & Mode & $471^{*}$ \\
\hline MA & 12 & Mode & $1^{*}$ \\
\hline $\mathrm{Ml}$ & 57 & Mode & \\
\hline $\mathrm{MN}$ & 52 & Mode & \\
\hline MS & 3 & Mode & \\
\hline $\mathrm{MO}$ & 8 & Mode & \\
\hline MT & 12 & Mode & $3^{*}$ \\
\hline $\mathrm{NE}$ & 28 & Mode & \\
\hline NV & 3 & Function & \\
\hline $\mathrm{NH}$ & 7 & Mode & 6 \\
\hline $\mathrm{NJ}$ & 19 & Mode & \\
\hline NM & 7 & Mode & 4 \\
\hline NY & 13 & Mode & \\
\hline $\mathrm{NC}$ & 22 & Mode & \\
\hline ND & 5 & Mode & $1^{*}$ \\
\hline $\mathrm{OH}$ & 30 & Mode & \\
\hline $\mathrm{OK}$ & 7 & Transportation & \\
\hline OR & 17 & Other & 7 \\
\hline PA & 41 & Mode & \\
\hline $\mathrm{RI}$ & 125 & Mode & $138^{*}$ \\
\hline $\mathrm{SC}$ & 13 & Mode & \\
\hline SD & 12 & Mode & \\
\hline $\mathrm{TN}$ & 32 & Mode\&Function & \\
\hline
\end{tabular}




\begin{tabular}{|c|c|c|c|}
\hline TX & 37 & Mode & \\
\hline UT & 11 & Mode & \\
\hline VT & & Function & $7^{*}$ \\
\hline VA & 32 & Mode & \\
\hline$\overline{W A}$ & 10 & Mode & 1 \\
\hline WV & 2 & Function & \\
\hline WI & 40 & Mode & 1 \\
\hline$\overline{W Y}$ & 11 & Mode & \\
\hline Total & 7,792 & & GRAND TOTAL=9993 \\
\hline
\end{tabular}

*Personnel assigned to operate State Owned Aircraft + Personnel assigned to operate State Owned Airports.

Source: National Association of State Aviation Officials (2001) State Aviation Funding and Organizational Data 